\title{
Efforts to Improve Mathematics Learning Achievement Through the Make A Match Learning Model in Class III Students of SDN Brebeg 01 Jeruklegi
}

\section{Fajar Solikhin}

SD Negeri Brebeg01

aufanaja87@gmail.com

\section{Article History \\ accepted 01/11/2020}

approved 08/11/2020 published 15/11/2020

\begin{abstract}
This article describes efforts to improve mathematics learning achievement through the make a match learning model for grade III students of SD Negeri Brebeg 01 in the 2020/2021 learning year. This study uses two cycles. Where each cycle begins with planning, implementing, observing, and reflecting. The results of this study were that in cycle 1 there was an increase in pre-cycle, 65.52\% of students completed and in cycle 2 there was an increase from cycle 1, $86.94 \%$ of students completed from 23 students. These results indicate that the make a match learning model can improve student achievement in determining the place value of a number in class III SD Negeri Brebeg 01.
\end{abstract}

Keywords: Achievements, make a match, Class III

\begin{abstract}
Abstrak
Artikel ini menjelaskan tentang upaya meningkatkan prestasi belajar matematika melalui model pembelajaran make a match untuk peserta didik kelas III SD Negeri Brebeg 01 tahun pembelajaran 2020/2021. Penelitian ini menggunakan dua siklus. Dimana setiap siklusnya dimulai dengan perencanaan, pelaksanaan, observasi, dan refleksi. Hasil dari penelitian ini adalah pada siklus 1 terlihat peningkatan dari pra siklus, 65,52\% peserta didik tuntas dan pada siklus 2 terlihat peningkatan dari siklus 1, 86,94\% peserta didik tuntas dari 23peserta didik. Hasil iini menunjukkan bahwa model pembelajaran make a match dapat meningkatkan prestasi peserta didik dalam menentukan nilai tempat pada suatu bilangan pada kelas III SD Negeri Brebeg 01.
\end{abstract}

Kata kunci: Prestasi, make a match, Kelas III

Social, Humanities, and Education Studies (SHEs): Conference Series https://jurnal.uns.ac.id/shes 


\section{PENDAHULUAN}

Pendidikan memiliki peranan yang sangat penting dalam kehidupan manusia, karena dapat mempengaruhi perkembangan dalam seluruh aspek kepribadian dan kehidupannya. Pendidikan memiliki kekuatan yang dinamis dalam masa kehidupan manusia di masa depan. Dalam Peraturan Pemerintah Nomor 17 Tahun 2010 pasal 1 ayat 7 dijelaskan bahwa:

Pendidikan dasar adalah jenjang pendidikan pada jalur pendidikan formal yang melandasi jenjang pendidikan menengah, yang diselenggarakan pada satuan pendidikan berbentuk Sekolah Dasar dan Madrasah Ibtidaiyah atau bentuk lain yang sederajat serta menjadi satu kesatuan kelanjutan pendidikan pada satuan pendidikan yang berbentuk Sekolah Menengah Pertama dan Madrasah Tsanawiyah, atau bentuk lain yang sederajat.

Mustafa (Tri Wijayanti, 2011) menyebutkan bahwa matematika adalah ilmu tentang kuantitas, bentuk, susunan, dan ukuran, yang utama adalah metode dan proses untuk menemukan dengan konsep yang tepat dan lambang yang konsisten, sifat dan hubungan antara jumlah dan ukuran, baik secara abstrak, matematika murni atau dalam keterkaitan manfaat pada matematika terapan.

Berdasarkan data guru yang diperoleh dari hasil evaluasi peserta didik pada pembelajaran tema 1 Subtema 1 kelas III SD Negeri Brebeg 01 Tahun Pelajaran 2020/20201 pada muatan pembelajaran matematika masih rendah. Dari total peserta didik di kelas III sebanyak 23 siswa nilai rata - rata kelas mencapai 63,18 dari nilai KKM 75. Dimana 10 siswa (43,48\%) memenuhi KKM dan 13 siswa (\%,) belum memenuhi KKM. Selain itu, berdasarkan angket atau kuisioner terhadap sikap kerjasama dalam kegiatan pembelajaran masih rendah yaitu $55.00 \%$. Oleh karena itu, diperlukan pembelajaran yang dapat meningkatkan aktivitas siswa dalam proses pembelajaran.

Permasalahan di atas membutuhkan usaha pemecahan masalah agar peserta didik termotivasi dalam proses pembelajaran dan tujuan pembelajaran tercapai sehingga prestasi belajar peserta didik meningkat. Maka untuk mengatasi permasalahan tersebut perlu adanya penggunaan media pembelajaran yang dapat menarik minat belajar peserta didik sehingga peserta didik terangsang dalam melakukan proses pembelajaran, sehingga hasil belajar peserta didik dapat meningkat.

\section{PRESTASI BELAJAR}

Sri Anitah W (2009: 2.19) prestasi belajar merupakan kulminasi dari suatu proses yang telah dilakukan dalam belajar. Kulminasi akan selalu diiringi dengan kegiatan tindak lanjut. Prestasi belajar harus menunjukan suatu perubahan tingkah laku atau perolehan perilaku yang baru dari siswa yang bersifat menetap, fungsional, positif, dan disadari.

\section{MATEMATIKA}

Menurut Abraham S Lunchins dan Edith N Luchins (Erman Suherman, 2001), matematika dapat dijawab secara berbeda-beda tergantung pada bilamana pertanyaan itu dijawab, dimana dijawabnya, siapa yang menjawabnya, dan apa sajakah yang dipandang termasuk dalam matematika.

Mustafa (Tri Wijayanti, 2011) menyebutkan bahwa matematika adalah ilmu tentang kuantitas, bentuk, susunan, dan ukuran, yang utama adalah metode dan proses untuk menemukan dengan konsep yang tepat dan lambang yang konsisten, sifat dan hubungan antara jumlah dan ukuran, baik secara abstrak, matematika murni atau dalam keterkaitan manfaat pada matematika terapan.

\section{Pengertian Model Pembelajaran "Make a Match"}

Menurut Rusman (2011, h. 223) menyatakan, " Model Cooperatif Tipe Make A Match ( membuat pasangan ) Merupakan salah satu jenis dari metode 
pembelajaran cooperative". Model ini dikembangkan oleh Lorna Curan (1994). Salah satu cara keunggulan teknik ini adalah peserta didik mencari pasangan sambil belajar mengenai suatu konsep atau topik, dalam suasana yang menyenangkan.

Anita Lie ( 2008, h. 56) " Model Cooperatif Tipe Make A Match ( membuat pasangan ) Merupakan teknik belajar yang member kesempatan siswa untuk bekerjasama dengan orang lain. Teknik ini dapat digunakan dalam semua pelajaran dan semua tingkatan usia anak didik.

Suyanto ( 2009, h. 56 )" Model Cooperatif Tipe Make A Match adalah model pembelajaran dimana guru menyiapkan kartu yang berisi soal atau permasalahan dan menyiapkan kartu jawaban kemudian siswa mencari pasangan kartunya.

Berdasarkan pendapat diatas, dapat disimpulkan bahwa model pembelajaran make a match merupakan model pembelajaran yang mengajak mencari jawaban terhadap suatu pertanyaan yang mengajak siswa memahami konsep-konsep melalui permainan kartu pasangan. Permainan tersebut dibatasi waktu yang ditentukan dalam suasana belajar yang menyenangkan, selain itu model pembelajaran make a match melatih siswa untuk aktif, kreatif dalam pembelajaran sehingga materi mudah dipahami dan bertahan lama.

Berpedoman pada penjelasan di atas, maka peneliti menetapkan judul penelitian tindakan kelas: "Upaya Meningkatan Prestasi Belajar Matematika Melalui Model Pembelajaran Make a Match Pada Siswa Kelas III SDN Brebeg 01 Jeruklegi Tahun Pelajaran 2020/2021.

\section{METODE}

Penelitian ini menggunakan penelitian tindakan kelas yang merupakan tindakan reflektif oleh aktor untuk meningkatkan proses pembelajaran. Dalam hal ini McNift (1992:1) seperti dikutip Suyanto (1997:2) memandang PTK sebagai bentuk penelitian reflektif yang dilakukan oleh guru sendiri dan hasilnya dapat dimanfaatkan sebagai alat untuk mengembangkan kurikulum, sekolah, dan pengembangan dalam proses belajar mengajar dll.

Penelitian ini dilakukan 2 siklus. Siklus pertama dilaksanakan pada tanggal 22 Oktober 2020 dan siklus ke 2 dilaksanakan pada tanggal 2 November 2020. Subjek dari penelitian ini adalah Peserta didik Kelas III SD Negeri Brebeg 01 Semester 1 Tahun Pelajaran 2020/2021 dengan jumlah peserta didik sebanyak 23.

Data kuantitatif dalam bentuk prestasi belajar kognitif, dianalisis menggunakan teknik analisis deskriptif dengan menentukan rerata atau rerata. Data kuantitatif akan disajikan sebagai persentase. Data kualitatif disajikan dalam kalimat yang dipisahkan oleh kategori untuk mendapatkan kesimpulan. Data kualitatif ini diperoleh dari mengolah data yang diperoleh dari instrumen pengamatan aktivitas peserta didik atau instrumen pengamatan keterampilan guru.

\section{HASIL DAN PEMBAHASAN}

Sebelum melakukan siklus, peneliti melakukan proses pembelajaran dengan menggunakan metode ceramah dan tanya jawab dengan materi menentukan nilai tempat pada suatu bilangan dan diakhiri dengan memberikan soal. Nilai pra siklus selanjutnya digunakan untuk pembagian kelompok. Tindakan pra siklus ini dilakukan pada tanggal 15 Oktober 2020. Adapun nilai dari pra siklus sebagai berikut:

Tabel 1. Hasil Belajar Peserta didik Pra Siklus

\begin{tabular}{llcc}
\hline \multirow{2}{*}{ Nilai } & \multirow{2}{*}{ Kategori } & \multicolumn{2}{c}{ Pra Siklus } \\
\cline { 3 - 4 } & & Peserta Didik & $\%$ \\
\hline $85-100$ & Sangat Baik & 3 & $13,04 \%$ \\
\hline
\end{tabular}




\begin{tabular}{llcc}
\hline $75-84$ & Baik & 7 & $30,43 \%$ \\
\hline $55-74$ & Cukup & 10 & $43,48 \%$ \\
\hline $35-54$ & Kurang & 3 & $13,04 \%$ \\
\hline $0-34$ & Sangat Kurang & 0 & $0 \%$ \\
\hline Jumlah & & 23 & $100 \%$ \\
\hline
\end{tabular}

Dari nilai di atas ketuntasan belajar dari materi yang diajarkan dengan KKM 75, ada 10 peserta didik yang di atas KKM (43,47\%) sedangkan yang tidak tuntas ada 13 peserta didik (56,53\%).

\section{Siklus I}

Pada kegiatan pra siklus terlihat prestasi belajar dalam menentukan nilai tempat pada suatu bilangan peserta didik masih kurang. Terlihat dari hasil belajar bahwa masih banyak peserta didik yang nilainya dibawah KKM. Siklus I ini dilaksanakan pada tanggal 22 Oktober 2020. Pada siklus 1 guru menggunakan model pembelajaran make a match untuk dapat meningkatkan prestasi belajar peserta didik.

Tabel 2. Hasil Belajar Peserta didik Siklus I

\begin{tabular}{llcc}
\hline \multirow{2}{*}{ Nilai } & \multirow{2}{*}{ Kategori } & \multicolumn{2}{c}{ Pra Siklus } \\
\cline { 3 - 4 } & & Peserta Didik & $\%$ \\
\hline $85-100$ & Sangat Baik & 4 & $17,39 \%$ \\
\hline $75-84$ & Baik & 11 & $47,83 \%$ \\
\hline $55-74$ & Cukup & 8 & $34,78 \%$ \\
\hline $35-54$ & Kurang & 0 & $0 \%$ \\
\hline $0-34$ & Sangat Kurang & 0 & $0 \%$ \\
\hline Jumlah & & 23 & $100 \%$ \\
\hline
\end{tabular}

Dari nilai di atas ketuntasan belajar dari materi yang diajarkan dengan KKM 75, ada 15 peserta didik yang di atas KKM (65,52\%) sedangkan yang tidak tuntas ada 8 peserta didik $(34,78 \%)$.

Pada siklus 1 rata rata kelas yang diperoleh adalah 76,39. Dari data tersebut terdapat kenaikan dari $43,47 \%$ peserta didik yang tuntas pada pra siklus menjadi $65,52 \%$ yang tuntas pada siklus I.

\section{Siklus II}

Pada siklus I setelah guru menggunakan model pembelajaran make a match peserta didik sudah mengalami peningkatan. Hanya saja masih ada beberapa peserta didik yang masih mengalami kesulitan. Sesuai dengan hasil refleksi siklus I di atas maka diadakan perbaikan tindakan kelas siklus II pada matematika materi menentukan nilai tempat pada suatu bilangan di kelas III SD Negeri Brebeg $01 \mathrm{Kec}$. Jeruklegi Kab.Cilacap semester 1 tahun pelajaran 2020/2021. Pada Siklus II ini dilakukan pada tanggal 2 November 2020. Berikut adalah hasil dari siklus II.

Tabel 3 Hasil Belajar Peserta didik Siklus II 


\begin{tabular}{llcr}
\hline \multirow{2}{*}{ Nilai } & \multirow{2}{*}{ Kategori } & \multicolumn{2}{c}{ Pra Siklus } \\
\cline { 3 - 4 } & & Peserta Didik & $\%$ \\
\hline $85-100$ & Sangat Baik & 6 & $26,09 \%$ \\
\hline $75-84$ & Baik & 14 & $60,87 \%$ \\
\hline $55-74$ & Cukup & 3 & $13,04 \%$ \\
\hline $35-54$ & Kurang & 0 & $0 \%$ \\
\hline $0-34$ & Sangat Kurang & 0 & $0 \%$ \\
\hline Jumlah & & 23 & $100 \%$ \\
\hline
\end{tabular}

Dari nilai di atas ketuntasan belajar dari materi yang diajarkan dengan KKM 75 ada 20 peserta didik $(86,96 \%)$ yang tuntas. Sedangkan yang tidak tuntas ada 3 peserta didik (13,04\%). Rata rata kelas pada siklus ini adalah 84,48.

Penilaian hasil pada siklus II menunjukkan guru sudah dapat memberikan motivasi pada peserta didik, guru sudah dapat mengunakan model pembelajaran make a match dengan baik, guru sudah dapat mengelola kelas dengan baik dan guru sudah dapat membuat setting kelas dengan baik terutama yang dapat menjadikan peserta didik menjadi aktif.

Tabel di atas membuktikan dengan beberapa tindakan yang dilakukan guru terutama dalam membimbing peserta didik dan memotivasi untuk aktif maka terjadi peningkatan prestasi belajar peserta didik pada muatan pelajaran matematika materi menentukan nilai tempat pada suatu bilangn di kelas III SD Negeri Brebeg $01 \mathrm{Kec}$. Jeruklegi Kab. Cilacap semester 1 tahun pelajaran 2020/2021 pada tingkat ketuntasan yang diinginkan dan dapat meningkatkan prestasi belajar peserta didik sebagaimana yang telah direncanakan.

Menurut Rusman (2011, h. 223) menyatakan, "Model Cooperatif Tipe Make A Match ( membuat pasangan ) Merupakan salah satu jenis dari metode pembelajaran cooperative". Model ini dikembangkan oleh Lorna Curan (1994). Salah satu cara keunggulan teknik ini adalah peserta didik mencari pasangan sambil belajar mengenai suatu konsep atau topik, dalam suasana yang menyenangkan.

\section{SIMPULAN}

Berdasarkan hasil penelitian dan diskusi, dapat disimpulkan bahwa:

1. Penggunaan model pembelajaran make a match pada pembelajaran tema 1 subtema 1 dapat prestasi belajar peserta didik kelas III SD Negeri Brebeg 01. Dilihat dari peningkatan prestasi peserta didik, ini membuktikan bahwa Pembelajaran tema 1 subtema 1 menggunakan model pembelajaran make a match sangat efektif untuk membantu peserta didik lebih memahami isi dan konsep materi serta berdampak pada peningkatan hasil prestasi belajar peserta didik.

2. Analisis hasil prestasi belajar menunjukkan bahwa nilai rata-rata kelas meningkat. Pada saat Pra tindakan rata-rata kelas 55,76 setelah menjadi subjek tindakan pada siklus I nilai rata-rata kelas meningkat menjadi 76,69 dan meningkat lagi pada siklus II menjadi 84,48 . Peserta didik yang dapat memenuhi ketuntasan belajar juga mengalami peningkatan, awalnya pada tindakan pra siklus ada 10 peserta didik atau sama dengan 43,48\% pada tindakan siklus I menjadi 15 peserta didik atau sama dengan 65,22\%, dan meningkat lagi pada tindakan siklus II menjadi 20 peserta didik atau sebesar $86,96 \%$. sehingga dapat disimpulkan bahwa penggunaan model pembelajaran make a 
match dapat meningkatkan prestasi belajar peserta didik kelas III SD Negeri Brebeg 01 dalam mempelajari pembelajaran tema 1 subtema 1.

\section{DAFTAR PUSTAKA}

Republik Indoneisa (2010) Peraturan Pemerintah Nomor 17 Tahun 2010 tentang Pengelolaan dan Penyelenggaraan Pendidikan.

Mustafa, Wijayanti Tri (2011). Pengertian Matematika. Jakarta: PT Gramedia

Anitah.W,Sri.dkk . 2009. Strategi Pembelajaran di Sekolah Dasar. Jakarta; Penerbit Universitas terbuka

Erman Suherman, dkk, Strategi Pembelajaran Matematika Kontemporer, (Bandung: JICAUPI, 2001), h.15

Anita Lie. 2008. Cooperative Learning. Jakarta: PT Grasindo.

Suyanto. 1997. Pedoman PelaksanaanPenelitian Tindakan Kelas (PTK)., Bagian satu. Jakarta: Dirjen Dikti Depdikbud Proyek Pendidikan Tenaga Akademik Bagian Pengembangan Pendidikan Guru Sekolah Dasar (BP3GSD).

Mihtahul Huda. 2013. Model-model Pengajaran dan Pembelajaran. Yogyakarta: Pustaka Pelajar.

Rusman. 2011. Model-model Pembelajaran Mengembangkan Profesionalisme Guru. Jakarta: Rajawali Pers. 